\title{
A REPLY TO JUDGE STARR'S OBSERVATIONS
}

\author{
ABNER J. MikVA*
}

We are no longer the common law courts that perhaps we once were. We are statutory courts. The overwhelming share of our business is the interpretation of what Congress, and the state legislatures, say the law is. I would hope that we engage in some reasoned dialogue with them, and maybe agree on some things, but they are the primary branch of government. A problem arises, then, when Congress does not speak as plainly as we would like them to speak.

Why doesn't Congress speak more plainly? Is it because congressmen all have marbles in their mouths? Is it because they are a bunch of dummies? That's not it. At a recent count, forty-four percent of the members of Congress were lawyers. I assure you that most of the actors, the prime movers in the first branch of government, know exactly what the process is about. They understand the use of language; they understand its uses and its limitations. No, the real problem is that we start out with 435 prima donnas in the House and 100 prima donnas in the Senate, and the name of the game is to get them to agree on a single set of words. We are not talking about trying to get Congress to agree on something unimportant or noncontroversial, like whether to declare Grandmother's Day. Instead, we are talking about the hard issues, like the environment, economic decisions and civil rights.

Those 535 people that we described are going to find it difficult to agree on an agenda, let alone on the words to describe whatever consensus they reach. The consensus that is reached to get a bill passed in the first place is a tenuous and confused one. Is it any wonder that the words they do finally choose tend to have diffuse and ambiguous meanings?

My favorite story along these lines involves Representative Morris Udall's passage of the strip-mining law, Act of August 3, 1977, Pub. L. No. 95-87, 91 Stat. 445 (codified at scattered sections of 18 U.S.C. and 30 U.S.C. (1982)). This was a typical piece of legislation. He had passed it through the House one time but could not move it in the Senate. The next time he passed a bill through both the House and the Senate, and President Ford vetoed it. Fe finally got a Democratic president who committed himself to signing a bill if Representative Udall could get it

* United States Circuit Judge, United States Court of Appeals for the District of Columbia 
through Congress. Because strip mining is one of the more confrontational issues that the nation faces, there were directly opposing views to reconcile in fashioning a bill. The miners and mine owners, the "states' righters," and the environmentalists each have very strong views on what the strip-mining laws should be.

Representative Udall fashioned a compromise and got it out of the committee and onto the floor. At one point, in his effort to shepherd the compromise through the House of Representatives, Udall, as floor manager, was explaining why it was a great bill and why it ought to be passed. One of the congressmen from West Virginia, a strip-mining state, arose and asked if the gentleman from Arizona would assure him that this bill would carefully protect states' rights and state sovereignty and that the states would continue to perform their role in managing strip mining within their borders. Representative Udall solemnly assured the gentleman that he was absolutely correct, that the bill very carefully preserved the role of the states in the process-state sovereignty was not impinged upon in any form. Twenty minutes later a pro-environmentalist congressman arose and asked if the gentleman from Arizona would assure him that the bill, once and for all, set single standards for strip mining and ensured that one federal law would cover strip mining throughout the country. Representative Udall assured the gentleman that he was absolutely correct, that this bill, once and for all, set uniform federal standards. Some of us were sitting in the cloakroom during this exchange; when Representative Udall came out for a drink of water one of the congressmen who had been listening in told him that both positions could not be right. Udall then assured that gentleman that he was absolutely correct.

It is not surprising that when the statute came before the courts there were some ambiguities. It simply was not as clear as it might have been in describing when the state was supposed to act and when the federal government was supposed to act. And yet, what should Congressman Udall have done-spend another twenty years trying to find more precise words to set forth his ideas concerning proper strip-mining law, even though he might never get 218 of his colleagues to agree with him again? It is this exigency that makes the necessity of reviewing legislative history an absolute given.

I am convinced that there simply is no way we can go back to those good old days when courts spent ninety-five percent of their time carefully moving the law forward in the common law process. It makes no sense to compare ourselves to the English courts, which function in an altogether different reviewing capacity than we do. England does not have a written constitution; therefore the kinds of inquiries that can 
come before their courts are much more limited than the ones that come before our courts. English courts interpret the law on its face while we have the duty to also determine the validity of the law itself by measuring it against the Constitution.

We are stuck with the proposition that Congress is going to pass laws that require interpretation, deal with more and more complicated subjects and involve more and more techmical expertise. Therefore, the words are going to be more and more difficult to comprehend. Most state constitutions still have "antimultifariousness" provisions that say the legislature cannot cover more than one subject in a bill. If the legislature has two subjects in a bill, the whole bill is unconstitutional. There is no such proscription on the federal legislature. The Congress is just as apt to pass a whole new criminal law as a rider to a continuing resolution as it is to consider subjects in some kind of diverse fashion.

It is true, of course, that if Congress has not done its job, the courts should not do it for them. Courts should not legislate; it is not our role. Many times the ambiguity in a statute is in a genuine zone of unresolved policy; the courts ought to recognize those situations and leave them alone. On the other hand, it is often the case that Congress is saying, "We're using this fuzzy langnage in the statute, but this is what we really mean." In those cases, we as judges have to look at the committee reports and at other clues. And we do have to look. We cannot just tell Congress that they could have said it more plainly, and that until they do, we are not going to enforce it. We can't say, "We pass."

Consider the strip-mining legislation, and let me exaggerate it just slightly. One provision of the bill provides that the state shall do $\mathrm{X}$ and one provision of the bill provides that the federal government shall do $\mathrm{X}$. What should a judge do when the two contenders come to court on this issue? Should the judge say, "I've got to go fishing"? Or should the judge say, "On the one hand they say this and on the other hand they say that. Now I've got to go fishing"? I thimk that the role of an Article III court must be to find a resolution to such ambiguities.

With respect to the Udall dispute, I would have gone back to the committee report, as I think most of the judges who were involved in the various disputes did. I would have resolved most of the disputes in favor of federal supremacy-on the ground that most of the fight over this statute was about whether there was going to be a set of federal standards superimposed on the states. That is, in fact, the way most of the cases were resolved.

As long as Congress continues to pass complicated, multifarious bills in devious ways, and sweeps difficult disagreements under the rug, the courts are going to have to interpret those statutes as best they can. I 
think, therefore, that courts would be well advised to try to find some common vocabulary and some common rules, and to give up the hopeless task of saying that we are no longer going to look outside the words of the statute. We cannot insist on calling a statute as Congress writes it. There are very few statutes which on their face clearly express what Congress intended.

An interesting and related question is how a court's interpretive role compares with an admimstrative agency's interpretive role with respect to a statute which the agency is charged with carrying out, and in which Congress has not been clear. In its pure terms, I have no problem with the concept articulated in Chevron U.S.A. Inc. v. Natural Resources Defense Council, Inc., 467 U.S. 837 (1984). If the law is clear, the courts ought to interpret it, even if the agency has come out the other way. If there are any ambiguities, however, courts ought to defer to the agencythe group of experts to whom Congress has given the first bite. But although judges agree with this theory, there is grave confusion about the application of the theory to real cases-and the real cases come up when Congress is silent about something.

In these cases, should the agency be able to read anything it wants into the statute? I cannot believe that this is what the Court meant in Chevron. I am sure that no one on the Supreme Court now, or at any time in our history, would say that the agency should be allowed to write its own mandate. The members of administrative agencies are not elected. They are not accountable to anyone, other than possibly the Appropriations Committee the next time the agency's budget is considered. If the statute is silent about something, then the agency's power slould be limited, just as the courts' power ought to be linnited. For example, in Chevron it seemed to me to be very clear that because the statute hadn't said anything about a "bubble concept," it was improper for the agency to fashion that power for itself. Of course, it is in these areas that the courts liave the most trouble because, most of the time, the agency is going through the same woods that courts have to go through. The law simply is not as clear as it ought to be. In these situations, courts sliould recognize that Congress entrusted agencies witl expert responsibility. Unless the agency itself has tried to write the statute, agencies ought to be given every deference and treated as experts. If the agency has tried to write the statute, the courts' expertise ouglit to take over. We ought to tell the agency that it exceeded its power.

I have tried to make clear that frequently a statute's plain meaning is not going to be easily discerned, and it is not going to be discerned at all if the judges and courts do not look at the legislative history. Unfortunately, this does not end discussion about legislative history because 
frequently the process of "making legislative history" is abused. In fact, that very term used to offend me when I was in Congress. Nothing made me squirm more than when some lawyer, who ought to have known better, would get up for the purpose of "making legislative history," saying, "watch me, I'm making history"-and then proceed to read a speech that had been prepared for him before he got to the floor.

Even more offensive is the pas de deux that frequently occurs on the floor. Two members will rise and engage in a colloquy for the purpose of "making legislative history." Frequently, however, the colloquy is written by just one of the members, not both. It is handed to the other actor and the two of them read it like a grade $B$ radio script. And that is the material that judges later will solemnly pore over, under the guise of "studying the legislative history." This, of course, is ridiculous. The problem is that judges don't know as much as they ought to know about the legislative process. Judges, who are educable, ought to be able to learn about how the process works, just as congressmen ought to be able to learn about how the judicial review process works. With more interchange than now occurs, these two branches ought to be able to agree on common rules of behavior so that when a judge talks about debate, he is talking about real debate and not the phenomenon I have just described. In turn, Congress ought to undertake more reform measures like the "bullet" rule, which requires that any speech or remarks in the Congressional Record by an absent member of Congress be preceeded by an asterisk or "bullet." This was not a far-reaching, overwhelming reform, but it was a step in the right direction. Now a judge can tell when a member was present on the floor and was saying something or when, in fact, he was off in Miami basking in the sun while his staff put some extracurricular remarks in the interoffice mailbox, which then appeared at the appropriate place in the record.

Congress and the judges should also agree on some canons of interpretation. There is room for some interpretive rules, if used by each branch. (At times I am somewhat dismayed, though, to talk about the problem of ejusdem generis when most of the Congress does not know what $I$ am saying and does not care about what $I$ am saying, even as I am saying it.) Perhaps a rule could be fashioned to govern when congressional silence is to be deemed assent, rather than what is usually the case: that most of the time Congress does not read judicial opinions and does not know whether courts properly interpreted the statute.

Perhaps staff members of the relevant committees ought to be required to read judicial opinions interpreting statutes. Then, at least, they would know what has happened to that beautiful work of art they sent out into the world, and how the courts now function under it. There is 
an interrelationship between the two branches: the Congress makes the laws and the courts interpret the laws. We ought to be more cognizant of that interrelationship.

In the absence of these reforms, we still must deal with the problem of resolving fine ambiguities in a statute, ambiguities where courts really do not know what a Congress had in mind. My approach is to go to the place in the legislative history where the majority did focus on the ambiguity. To this end, I always find that the committee report is the most useful device; it is what I use to try to resolve some of those ambignities. Most of the time-not always, and not for every committee-the committee report represents the synthesis of the last meaningful discussion and debate on the issue. The committee report is usually drafted by the majority staff, more often than not with substantial input from the minority on the committee. Indeed, because the committee report is so useful, one of the reforms that I would advocate is that the chairman and the staff stop using the committee reports to engage in horse trading and logrolling.

I have argued here that the use of legislative history is compelled by the inherent ambiguities of statutes, ambiguities behind which often lie a discernable congressional intent. I have also tried to describe some reforms that would allow courts to use legislative history more reliably and more efficiently. Now, I would like to respond to the notion that with respect to the use of legislative history, one school of thought abnegates political power, while the other school grabs it. This is just not so. A scheme of judicial interpretation of statutes that eschews the use of legislative history can easily come to rely upon the significance of the use, or omission, of certain prepositions, or even the placement of commas and semi-colons. Let me put the commas and semi-colons where I claim they are meaningful, and let me interpret the "plain words" of a statute, and I can exercise all kinds of power that I probably should not.

My own feeling is that judicial restraint starts with the proposition that a judge is not supposed to be making policy decisions. People who have been in the public arena make good judges because most of us have had an opportunity to test our policy ideas; either they did not get adopted or, when they did get adopted, they turned out not to be so great after all. I am perfectly delighted to let other people make policy decisions at this point. I tried making them for over twenty years and the republic isn't much more secure for my twenty years of effort than it was before I started.

As judges we are not supposed to do what the legislative branch does-we are not supposed to try to do it better; we are not supposed to finish the task; and we are not supposed to get into areas that the legisla- 
ture did not get into. Democratic theory not only requires courts to give appropriate deference to the first branch, but also to recognize that the elected policymakers make the law, and therefore the law is what they say it is. Congress is like HHumpty Dumpty in Through the Looking Glass. When Congress uses a word, the word means what Congress says it means, all the dictionary definitions to the contrary notwithstanding. If Congress has established what it wants a word to mean, that is what it means.

The question, of course, is how to make this primacy meaningful. One thing to bear in mind is that while judges should not take their role of interpreting statutes lightly, the job is not quite so awesome as interpreting the Constitution of the United States. When an Article III judge interprets the Constitution, only higher judges can correct a misinterpretation. But when a judge misinterprets a statute that Congress has written, Congress can correct the error. Sometimes the ink isn't dry on some of our decisions when Congress has made it clear that it disagrees. There is an opinion on page 98 of volume 342 of the United States Reports, United States $v$. Wunderlich (1951), interpreting a federal statute, which is almost word for word the way I drafted it for Justice Minton. It lasted less than three months before Congress overruled it in its entirety. It gives me some solace to know that even if I am wrong, Congress is there to correct me.

If judges are to make congressional primacy meaningful, they cannot afford to ignore those obvious tools which members of Congress use to explain what they are doing and to describe the meaning of the words used in the statute. Those who refuse to use the tools are merely saying that they don't want to look. Their feeling is that you ought not to look at the legislative process if you want to digest it because it is just too messy and untidy. But the alternative is to give a judge the relatively unrestrained power to look just at the statute's words and at Webster's Dictionary, and to decide with Webster's what the law of the land will be. I would rather the judge use all the tools that are available. Fortunately, if he is wrong, Congress can correct him. 